\title{
Identification of Pecan Cultivars and Their Genetic Relatedness as Determined by Randomly Amplified Polymorphic DNA Analysis
}

\author{
Patrick J. Conner ${ }^{1}$ \\ Department of Horticulture, University of Georgia, Coastal Plain Experiment Station, 4604 Research \\ Way, Tifton, GA 31793 \\ Bruce W. Wood \\ U.S. Department of Agriculture, Agricultural Research Service, Southeastern Fruit and Tree Nut \\ Research Laboratory, 21 Dunbar Road, Byron, GA 31008
}

AdDitional INDEX words. RAPD, genetic markers, DNA, fingerprinting, nut, tree breeding, hickory, Carya illinoinensis

\begin{abstract}
Genetic variation among pecan [Carya illinoinensis (Wangenh.) C. Koch] cultivars was studied using randomly amplified polymorphic DNA (RAPD) markers. Using a combination of primers, a unique fingerprint is presented for each of the pecan genotypes studied. The genetic relatedness between 43 cultivars was estimated using 100 RAPD markers. Genetic distances, based on the similarity coefficient of Nei \& $\mathrm{Li}$, varied from 0.91 to 0.46 , with an average value of 0.66 among all cultivars. The phenetic dendrogram developed from cluster analysis showed relatively weak grouping association. However, cultivars with known pedigrees usually grouped with at least one of the parents and genetic similarity estimates appear to agree with known genetic relationships.
\end{abstract}

The pecan (Carya illinoinensis) is a recently established nut crop and the most economically important member of the genus Carya Nutt. (hickory) (Wood, 1994). Its native distribution is from north central and eastern United States into southern Mexico (Grauke et al. 1995). Pecan was widely used as a food source by indigenous peoples and early settlers (Grauke and Thompson, 1996). However, commercial orchard production and cultivar propagation did not begin until the latter half of the $19^{\text {th }}$ century, and production by cultivars did not exceed native and seedling trees until 1958 (Wood et al., 1990). Currently, most cultivars represent at most two generations of controlled crosses and many are seedling selections (Thompson and Young, 1985).

Due to its recent domestication, the small number of pecan geneticists, and the inherent difficulties of working with a large perennial tree, a relative paucity of genetic knowledge exists for pecan. Only two distinct genetic markers, a lace-leaf phenotype (Marquard, 1991b) and dichogamy type (Thompson and Romberg, 1985), have been found. Several isozyme systems have been developed for pecan (Marquard, 1987, 1989, 1991a; Marquard et al. 1995; Ruter et al. 1999) and have proven useful for studying genetic diversity in natural and cultivated germplasm collections (Grauke et al., 1995; Ruter et al., 1999; Wood et al., 1998), and determining outcrossing rates (Marquard, 1988). However, the relatively small number of isozyme markers reduces their utility in fingerprinting and assessing genetic relationships among cultivars.

Development of polymerase chain reaction (PCR)-based marker systems, especially randomly amplified polymorphic DNA (RAPD) markers, (Williams et al., 1990) has proven quite useful in genetic studies. RAPD markers combine the advantages of low technical input with almost unlimited marker numbers. RAPD markers have been used to determine genetic relationships

Received for publication 11 Sept. 2000. Accepted for publication 13 Feb. 2001 The cost of publishing this paper was defrayed in part by the payment of page charges. Under postal regulations, this paper therefore must be hereby marked advertisement solely to indicate this fact.

${ }^{1}$ Corresponding author; e-mail: pconner@tifton.cpes.peachnet.edu. among breeding materials and fingerprint cultivars in many woody plant crops including: blueberry (Vaccinium L. sp.) (Aruna et al., 1993; Levi and Rowland, 1997), Persian walnut (Juglans regia L.) (Nicese et al., 1998), Prunus L. rootstocks (Casas et al., 1999), date palm (Phoenix dactylifera L.) (Sedra et al., 1998), mango (Mangifera indica L.) (Schnell et al., 1995), and almond (Prunus dulcis (Mill.) D.A. Webb) (Bartolozietal et al., 1998).

Understanding the genetic relationships of frequently used germplasm is vital to any breeding program wishing to increase the genetic diversity of new cultivars. In pecan this is difficult because many cultivars were developed in the late $19^{\text {th }}$ and early $20^{\text {th }}$ centuries by nurserymen who kept poor records and had inadequate protection against cross-pollination. Because of this, only the maternal parent, or neither parent, has been established for many cultivars. The objective of this study was to use RAPD markers to estimate genetic similarity among a group of cultivars of importance to the University of Georgia breeding program. In addition, RAPD-based DNA fingerprints were developed for each of the cultivars. These fingerprints are a valuable means of identification in pecan where cultivars are typically identified only after fruiting by nut morphology.

\section{Materials and Methods}

Plant material. Twelve of the 43 cultivars ('Burkett', 'Colby', 'Evers', 'Giles', 'Green River', 'Major', 'Mohawk', 'Odom', 'Peruque', 'Podsednik', 'Riverside', and 'Success') examined in this study were obtained from the cultivar collection at the USDA-ARS Fruit and Nut Research Unit, Byron Ga. Leaf material from the 'Jenkins' cultivar was kindly provided by William Goff at Auburn University, Auburn, Ala., and the remaining cultivars were obtained from the cultivar collections at the Coastal Plain Experiment Station, Tifton, Ga. Cultivars were selected based on their importance to the breeding program or their historical importance.

PCR AMPlification AND Electrophoresis. DNA extraction was based on a procedure developed by Porebski et al. (1997) for plants containing high polysaccharide and polyphenol compo- 


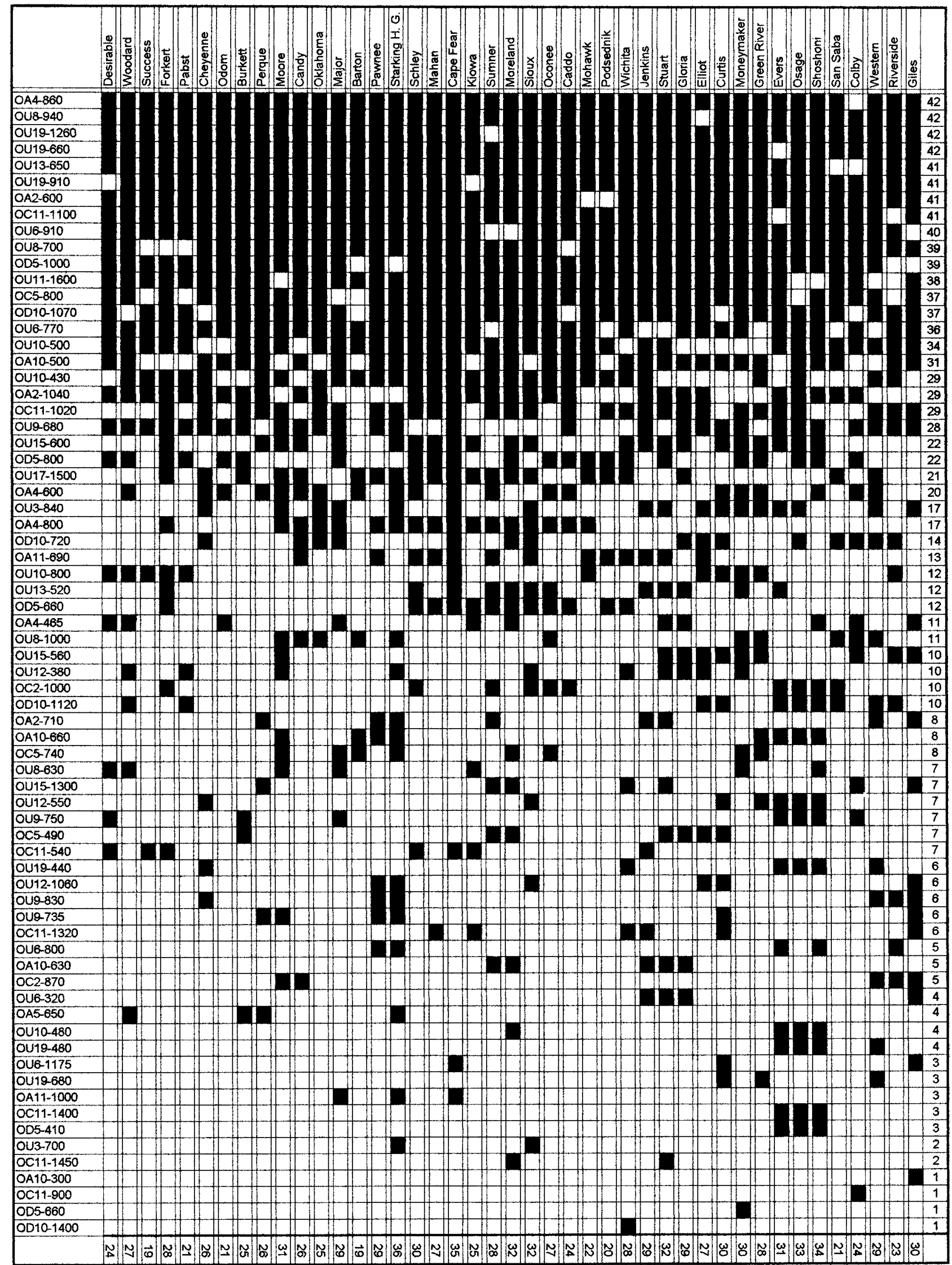

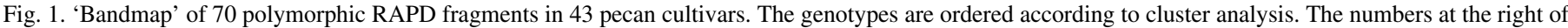
each row represent the number of cultivars producing the fragment. The numbers at the bottom of each column represent the number of fragments produced by that cultivar. Band names are at the left of each row, designated according to Operon primer name and fragment size. Shaded blocks represent the presence of DNA bands. 
nents. DNA concentration was determined by running DNA samples on a $1.4 \%$ agarose gel with known concentrations of DNA, ethidium bromide staining, and visual interpretation of band intensity. RAPD reactions were carried out in $25 \mu \mathrm{L}$ volumes consisting of $10 \mathrm{~mm}$ Tris- $\mathrm{HCl}(\mathrm{pH}=9.0), 50 \mathrm{~mm} \mathrm{KCl}$, $0.1 \%$ Triton X-100, $3 \mathrm{~mm} \mathrm{MgCl}_{2}, 200 \mu \mathrm{m}$ of each DNTP(Promega, Inc., Madison, Wis.), $0.6 \mu \mathrm{M}$ primer (Operon, Inc., Almeda, Calif.) and 1.0 U Taq DNA polymerase (Promega, Inc.) and either 2 or $8 \mathrm{ng}$ of DNA ( $8 \mathrm{ng}$ in the original amplification and $2 \mathrm{ng}$ in a separate replication). Amplifications were carried out using a Mastercycler gradient thermocycler (Eppendorf Sci., Westbury N.Y.) programmed as follows: 1 cycle of 2 min at $94{ }^{\circ} \mathrm{C}$, followed by 40 cycles of $45 \mathrm{~s}$ at $94{ }^{\circ} \mathrm{C}, 1 \mathrm{~min}$ at $36^{\circ} \mathrm{C}, 2 \mathrm{~min}$ at $72^{\circ} \mathrm{C}$ with a ramp speed of $0.3^{\circ} \mathrm{C} \cdot \mathrm{s}^{-1}$ between $36^{\circ} \mathrm{C}$ and $72^{\circ} \mathrm{C}$. The last cycle was followed by final incubation of $8 \mathrm{~min}$ at $72{ }^{\circ} \mathrm{C}$ and PCR products were stored at $4{ }^{\circ} \mathrm{C}$ until electrophoresis. The DNA amplification products were separated in a $0.7 \%$ agarose $0.35 \%$ synergel (Diversified Biotech, Boston) gels using 0.5× TBE buffer. Gels were stained with ethidium bromide and visualized under ultraviolet light. Band sizes were estimated by comparison to a 100 base pair (bp) DNA ladder (Promega, Inc.).

DATa AnAlYsis. RAPD bands were scored from digital pictures as either present (1) or absent (0) for all markers for all individuals in the study. From these data a similarity matrix was constructed by the NTSYS-pc version 2.02i (Rohlf, 1998) based on the Dice coefficient, also known as the similarity coefficient of Nei and Li (1979). The Dice coefficient is the number of RAPD bands present in both cultivars, divided by the average number of RAPD bands present in each sample. Clustering analysis was conducted using the unweighted pair-group method with arithmetic averages (UPGMA) and a dendrogram constructed. Similarity matrixes were compared using the Mantel matrix-correspondence test (Mantel, 1967).

\section{Results and Discussion}

Primer screening. Reproducibility of RAPD bands is highly dependent upon the constancy of the reaction conditions and small changes in these variables can lead to spurious results (Lamboy, 1994; Penner et al., 1993; Weising et al., 1995). In order to reduce the level of these errors, each sample was replicated in a separate PCR reaction using DNA from a different tree at a 4-fold lower concentration. These products were then run side by side on the gel and only bands that were consistently present or absent in both amplifications across all accessions were used in the analysis. Nearly all of the bands that were not consistent were either weakly amplified in one sample and not visible in the other sample or were over $2500 \mathrm{bp}$ in length.

In total, 75 decamer primers were screened using a subset of five cultivars: 'Desirable', 'Jenkins', 'Elliot', 'Wichita', and 'Evers'. Of the 75 primers evaluated, 25 were chosen to run on the entire cultivar set based on the number of clearly amplified polymorphic bands produced with these five cultivars. From the 25 primers, 100 reproducible polymorphic bands were scored for an average of four scorable polymorphic bands per primer. The number of scorable bands produced by each primer ranged from one to nine, and bands ranged in size from 320 to $1600 \mathrm{bp}$.

Cultivar Fingerprinting. All 43 cultivars in this study could be separated based on the RAPD fingerprints produced by one or more primers (Fig. 1). Seven cultivars-Giles, Colby, Evers, Moneymaker, Elliot, Wichita, and Sumner — could be identified through the presence of a single RAPD band that all other cultivars lacked or the absence of a single band that all other cultivars produced. All other cultivars required at least two bands to be scored for an indentification to be made. Therefore, RAPD markers have good potential for use in fingerprinting pecan cultivars. Judicious use of a few primers that produce multiple bands will provide a relatively high degree of certainty that the cultivar is correctly identified.

GENETIC RELATIONSHIPS AMONG SAMPLES. The cultivars analyzed in this study represent a wide range of germplasm originating from breeding programs, seedling orchards, and native stands from a wide geographical range (Table 1). The Dice similarity coefficients among cultivars ranged from 0.91 between 'Schley' and 'Mahan' to 0.46 between 'Elliot' and 'Barton', with an average value among all the cultivars of 0.66 (Table 2). The average genetic similarity of a parent with its offspring in this study was 0.80 , as compared to an overall average similarity of 0.66 among cultivars.

A dendrogram constructed from the similarity data shows relatively indistinct groupings among the different cultivars (Fig. 2). However, a few prominent groupings could be discerned. 'Success' and 'Pabst', were selected from the same seedling orchard (KenKnight, 1970) and may have a similar pedigree. These two cultivars are grouped with 'Desirable' and 'Forkert', both of which have 'Success' as the maternal parent. The largest group consists of 'Schley' and its likely progeny 'Mahan' along with 'Cape Fear', 'Kiowa', 'Moreland', 'Sioux', 'Oconee', 'Mohawk', and 'Wichita', all of which have 'Schley' or 'Mahan' as a parent. Other smaller clusters such as 'Evers', 'Osage', and 'Shoshoni' also represent parent cultivars and their progeny. The cophenetic correlation coefficient is a measure of the accuracy with which the dendrogram represents the similarity matrix constructed from the RAPD data (Warburton and Bliss, 1996). The correlation coefficient between the cophenetic matrix (data derived from the dendrogram) and the dice similarity coefficient matrix was relatively low at only 0.691 . The coefficient was most likely reduced because of the presence of several cultivars such as 'Forkert', 'Kiowa', and 'Pawnee' that are progeny of two cultivars that are not closely related. This forces the progeny to be grouped with only one of the parents, reducing the overall correlation coefficient. However, most progeny were grouped with at least one of the parents, supporting the accuracy of the similarity coefficients.

A large number of pecan cultivars are of unknown or questionable pedigree. This is because many were selected from seedling orchards where only the maternal parent or neither parent was known, or they were produced early in the century before efficient means of pollination control of this wind-pollinated species were established (Sparks, 1992). We were therefore interested in using the information gathered in this study to examine the putative origins of several cultivars.

'Schley' was reported to have been grown from a 'Stuart' nut (Taylor, 1906). Sparks (1992) called this parentage into question because of the lack of any obvious similarities between the two cultivars. Our results also do not support the likelihood of 'Schley' being a progeny of 'Stuart' because the similarity value between these two cultivars of 0.67 is only slightly greater than the overall average similarity of 0.66 among all cultivars.

'Mahan' is a well-known older cultivar that has been widely used in pecan breeding (Sparks, 1992). 'Mahan' originated from a seed planted $\approx 1910$ by J.M. Chesnutt (KenKnight, 1970). Thompson and Romberg (1985) proposed 'Schley' as a parent of 'Mahan' based upon inheritance of unnamed characters. They 
Table 1. Parentage and origin of pecan cultivars.

\begin{tabular}{|c|c|c|c|}
\hline Cultivar & Parentage $^{\mathrm{z}}$ & Origin $^{y}$ & Source date ${ }^{x}$ \\
\hline Barton & Moore X Success & Texas, Brownwood & 1937 \\
\hline Burkett & Native & Texas, Callahan Co. & 1900 \\
\hline Caddo & Brooks X Alley & Ga., Philema & 1922 or 1923 \\
\hline Candy & Seedling & Miss., Ocean Springs & 1913 \\
\hline Cape Fear & Schley Seedling & N.C., Willard & 1912 \\
\hline Cheyenne & Clark x Odom & Texas, Brownwood & 1942 \\
\hline Colby & Native & Ill., Clinton Co. & $\approx 1940$ \\
\hline Curtis & Turkey Egg Seedling. & Fla., Orange Heights & 1886 \\
\hline Desirable & Success $x$ Jewett & Miss., Ocean Springs & Early 1900's \\
\hline Elliot & Seedling & Fla., Milton & 1912 \\
\hline Evers & Seedling & Nut from Mex. or Texas & Before 1950 \\
\hline Forkert & Success $x$ Schley & Miss., Ocean Springs & $\approx 1913$ \\
\hline Giles & Native & Kan., Chetopa & $\approx 1927$ \\
\hline Gloria Grande & Seedling & S.C., Elloree & 1923 \\
\hline Green River & Native & Ky., Henderson & $\approx 1911$ \\
\hline Jenkins & Seedling & Miss., Rena Lara & 1977 \\
\hline Kiowa & Mahan X Desirable? & Texas, Brownwood & 1953 \\
\hline Mahan & Seedling & Miss., Kosciusko & 1910 \\
\hline Major & Native & Ky., Henderson & 1908 \\
\hline Mohawk & Success $x$ Mahan & Texas, Brownwood & 1946 \\
\hline Moneymaker & Seedling & La., Mound & $\approx 1885$ \\
\hline Moreland & Seedling & La., Powhatan & $\approx 1945$ \\
\hline Oconee & Schley $\times$ Barton & Texas, Brownwood & 1956 \\
\hline Odom & Seedling & Miss., Ocean Springs & 1923 \\
\hline Oklahoma & Native & Okla., Ardmore & $\approx 1912$ \\
\hline Osage & Major $x$ Evers & Texas, Brownwood & 1948 \\
\hline Pabst & Seedling & Miss., Ocean Springs & $\approx 1875$ \\
\hline Pawnee & Mohawk x Starking H.G. & Texas, Brownwood & 1963 \\
\hline Peruque & Native & Missouri, St. Charles & Before 1918 \\
\hline Podsednik & Seedling & Texas, Arlington & Unknown \\
\hline Riverside & Seedling & Texas, Big Valley & Unknown \\
\hline San Saba Improved & San Saba Seedling. & Texas, San Saba & 1895 \\
\hline Schley & Stuart Seedling? & Miss., Scranton & $\approx 1881$ \\
\hline Shoshoni & Odom $\times$ Evers & Texas, Brownwood & 1945 \\
\hline Sioux & Schley x Carmichael & Texas, Brownwood & 1943 \\
\hline Success & Seedling & Miss., Ocean Springs & $\approx 1890$ \\
\hline Starking H.G. & Native & Missouri, Brunswick & 1950 \\
\hline Stuart & Seedling & Miss., Pascagoula & $\approx 1874$ \\
\hline Sumner & Seedling & Ga., Tifton & $\approx 1932$ \\
\hline Western & Seedling & Texas, San Saba & 1895 \\
\hline Wichita & Halbert $x$ Mahan & Texas, Brownwood & 1940 \\
\hline Woodard & Seedling & Ga., Tift Co. & Before 1954 \\
\hline
\end{tabular}

${ }^{\mathrm{z}}$ Seedling denotes trees planted by man where one or both parents are unknown. Native indicates trees identified from a natural stand. Adapted from Thompson and Young (1985) and Sparks (1992).

${ }^{y}$ State, and town or county where original tree was grown.

${ }^{x}$ Year tree was identified, nut planted, or cross made.

also suggest that 'Mahan' may be a self of 'Schley' because 'Mahan' is homozygous dominant protogynous $(P P)$ for heterodichogamy. This is a rare genotype since most crosses are between protogynous $(P P$ or $P p)$ and protandrous $(p p)$ genotypes. The high similarity between 'Schley' and 'Mahan' (0.91) provides good support that 'Schley' is indeed a parent of 'Mahan'. However, the presence of three RAPD bands in 'Mahan' but not in 'Schley' (Fig. 1) does not support the hypothesis that 'Mahan' resulted from a self of 'Schley' because RAPD bands are inherited in a dominant manner.

The 'Sumner' cultivar was a seedling tree identified in Tift County, Ga., in $\approx 1932$. No record exists as to possible pedigree, but nut shape is similar to 'Schley' and it is occasionally sold as
"Jumbo Schley" (Sparks, 1992). The genetic similarity between 'Schley' and 'Sumner' is 0.82 , providing strong evidence that 'Schley' is a parent of 'Sumner'. The only other cultivar in this group with a similar level of similarity is 'Moreland', but 'Moreland' was developed after 'Sumner' and is likely a half-sib of 'Sumner'.

'Moreland' was propagated from a shoot originating below the graft union of a tree purchased from the Bass Pecan Company $\approx 1945$ (O'Barr et al., 1990). Because of its origin and similarity in appearance to 'Schley', 'Schley' has been proposed as a probable parent. 'Moreland' is genetically most similar to 'Schley' (0.79), 'Mahan' (0.80), and 'Sumner' (0.81) in this group of cultivars. Of these three, 'Sumner' is least likely to have been a 


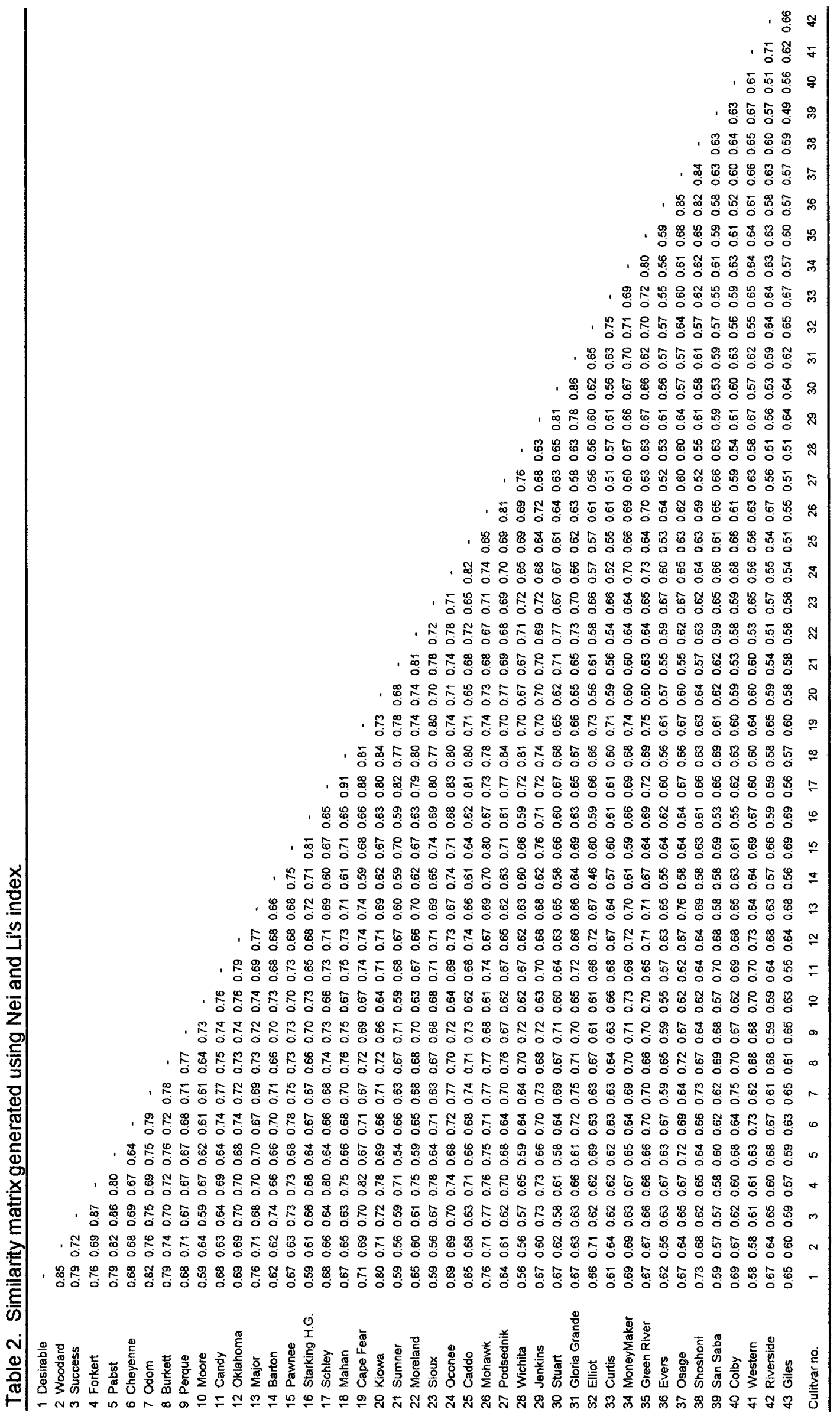


parent, because although the tree was discovered in 1932, it was not widely disseminated until recently (Sparks, 1992).

'Kiowa' was selected from a cross between 'Mahan' and 'Odom' in 1953 by L.D. Romberg of the U.S. Pecan Field Station, Brownwood, Texas. Isozyme analysis later indicated that this parentage was incorrect because both of the putative parents express the $b b$ genotype for the isozyme Mdh- 1 and 'Kiowa' has an $a b$ genotype at this allele (Marquard, 1987). The authors proposed that, based upon the similar morphology of the leaves, 'Mahan' was the maternal parent. 'Desirable' was proposed as a likely paternal parent based upon similarity of nut size and shape and isozyme genotype. Our results provide additional support for this inheritance given the high genetic similarity between 'Kiowa' and 'Mahan' (0.84) and 'Desirable' (0.80) (Table 2). The only other cultivar with an equally high similarity to 'Kiowa' is 'Schley' (0.80), which is the maternal parent of 'Mahan'.

'Gloria Grande' originated as a selection from a South Carolina seedling orchard (Worley, 1974). 'Stuart' has been suggested as a possible parent of 'Gloria Grande' due to the similarity in upright tree form and nut characteristics. The widespread planting of 'Stuart', and the high level of genetic similarity (0.86, Table 2$)$ between these two cultivars provides additional support for this conclusion.

Results of this study clearly indicate the utility of RAPD markers for the detection of genetic variation in pecan. RAPD markers have good potential for identifying pecan cultivars, and are especially useful in identifying reproductively immature trees. The genetic similarity values developed in this study provide pecan breeders with a starting point in designing crosses to increase the genetic diversity of their material. Although, little is known about the origins of many popular pecan cultivars, for the most part, these estimates show good agreement with known pedigrees. It is a testament to prior researchers' keenness of observation and familiarity with the plant material that many prior conclusions on the pedigree of these cultivars based upon physical similarities have been supported by this study.

\section{Literature Cited}

Aruna, M., P. Ozias-Akins, M. Austin, and G. Kochert. 1993. Genetic relatedness among rabbiteye blueberry (Vaccinium ashei) cultivars determined by DNA amplification using single primers of arbitrary sequence. Genome 36:971-977.

Bartolozzi, F., M.L. Warburton, S. Arulsekar, and T.M. Gradziel. 1998. Genetic characterization and relatedness among California almond cultivars and breeding lines detected by randomly amplified polymorphic DNA (RAPD) analysis. J. Amer. Soc. Hort. Sci. 123:381-387.

Casas, A.M., E. Igartua, G. Balaguer, and M.A. Moreno. 1999. Genetic diversity of Prunus rootstocks analyzed by RAPD markers. Euphytica 110:139-149.

Grauke, L.J. and T.E. Thompson. 1996. Pecans and hickories, p. 185239. In: J. Janick and J.N. Moore (eds.). Fruit breeding vol. III. Nuts. Wiley, New York.

Grauke, L.J., T.E. Thompson, and R.D. Marquard. 1995. Evaluation of pecan [Carya illinoensis (Wangenh.) K. Koch] germplasm collections

Fig. 2. Dendrogram of 43 pecan cultivars generated by UPGMA cluster analysis of the similarity values shown in Table 2 .

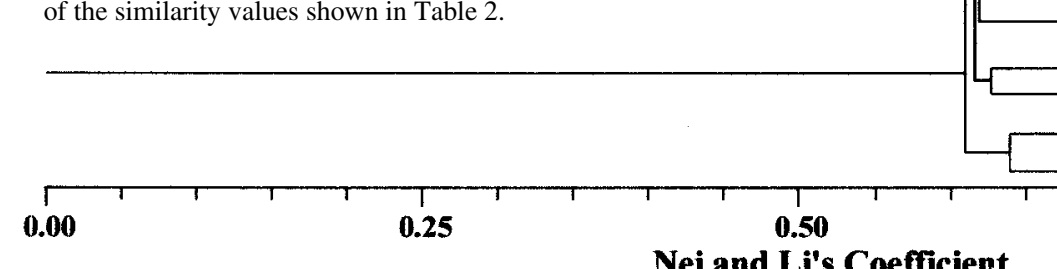

and designation of a core subset. HortScience 30:950-954.

KenKnight, G.E. 1970. Pecan varieties "happen" in Jackson County, Mississippi. Pecan Quarterly 4(3):6-7.

Lamboy, W.F. 1994. Computing genetic similarity coefficients from RAPD data: The effects of PCR artifacts. PCR Methods and Applications 4:3-37.

Levi, A. and L.J. Rowland. 1997. Identifying blueberry cultivars and evaluating their genetic relationships using randomly amplified polymorphic DNA (RAPD) and simple sequence repeat- (SSR-) anchored primers. J. Amer. Soc. Hort. Sci. 122:74-78.

Mantel, N.A. 1967. The detection of disease clustering and a generalized regression approach. Cancer Res. 27:209-220.

Marquard, R.D. 1987. Isozyme inheritance, polymorphism, and stability of malate dehydrogenase and phosphoglucose isomerase in pecan. $\mathbf{J}$. Amer. Soc. Hort. Sci. 112:717-721.

Marquard, R.D. 1988. Outcrossing rates in pecan and the potential for increased yields. J. Amer. Soc. Hort. Sci. 113:84-88.

Marquard, R.D. 1989. Rare allozymes of malate dehydrogenase in pecan. HortScience 24:156.

Marquard, R.D. 1991a. Inheritance of phosphoglucomutase isozymes in pecan. HortScience 26:1213-1214.

Marquard, R.D. 1991b. A novellace-leafed pecan. HortScience 26:1316-1317.

Marquard, R.D., L.J. Grauke, T.E. Thompson, and R.S. Janos. 1995. Identifying pecan cultivars by isozymes and inheritance of leucine aminopeptidase. J. Amer. Soc. Hort. Sci. 120:661-666.

Nicese, F.P., J.I. Hormaza, and G.H. McGranahan. 1998. Molecular characterization and genetic relatedness among walnut (Juglans regia L.) genotypes based on RAPD markers. Euphytica 101:199-206.

Nei, M. and W.H. Li. 1979. Mathematical model for studying genetic variation in terms of restriction endonucleases. Proc. Natl. Acad. Sci. USA 76:5269-5270.

O'Barr, R.D., W. Sherman, W.A. Young, W.A. Meadows, V. Calcote,

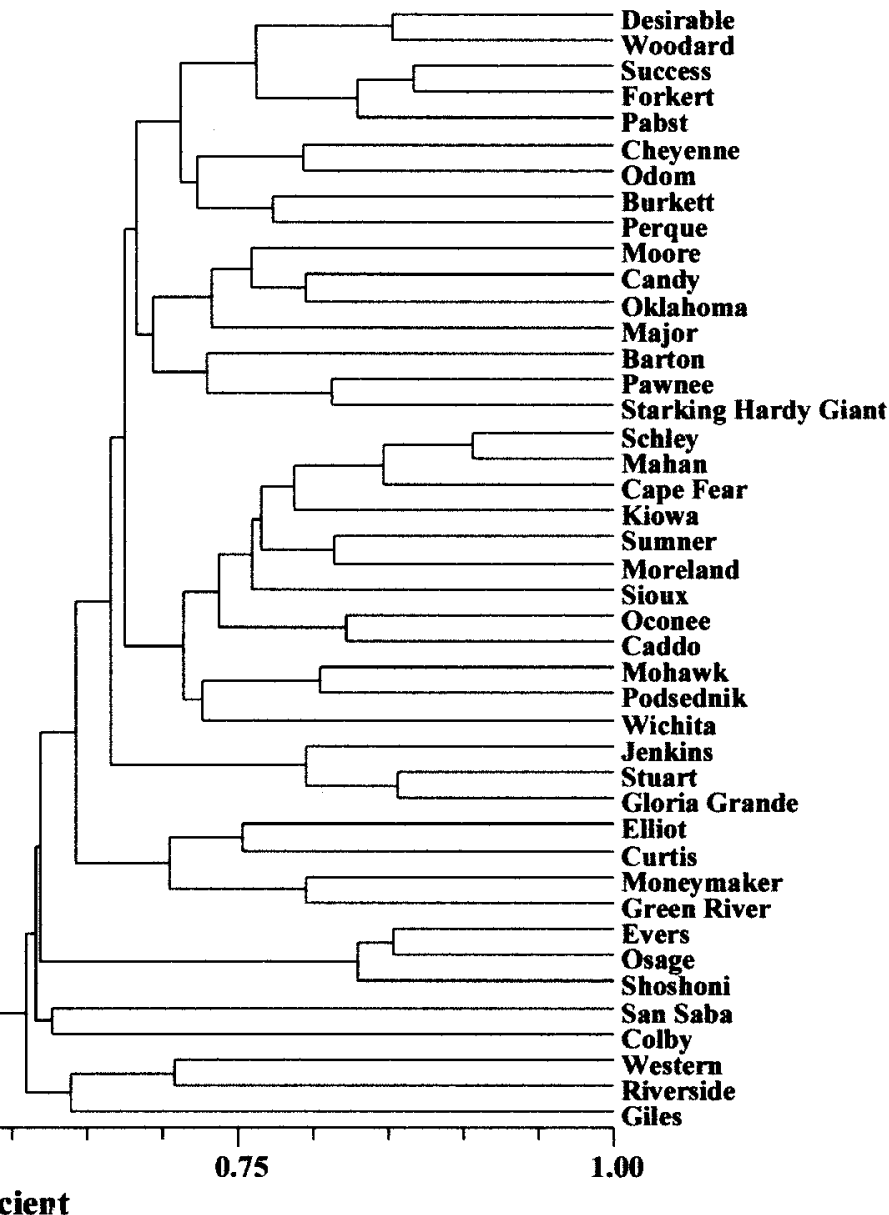


and G. KenKnight. 1990. 'Moreland' pecan. Proc. Southeastern Pecan Growers Assn. 83:107-112.

Penner, G.A., A. Bush, R. Wise, K.W. Domier, K. Kasha, A. Laroche, G. Scole, S. Molnar, and G. Fedak. 1993. Reproducibility of random amplified DNA (RAPD) analysis among laboratories. PCR Methods and Applications 2:341-345.

Porebski, S., L.G. Bailey, and B.R. Baum. 1997. Modification of a CTAB DNA extraction protocol for plants containing high polysaccharide and polyphenol components. Plant. Mol. Biol. Rpt. 15:8-15.

Rohlf, F.J. 1998. NTSYS-pc: Numerical taxonomy and multivariate analysis system. version 2.0. Applied Biostatistics, New York.

Ruter, B., J.J. Hamrick, and B.W. Wood. 1999. Genetic diversity within provenance and cultivar germplasm collections versus natural populations of pecan (Carya illinoensis). J. Hered. 90:521-528.

Schnell, R.J., C.M. Ronning, and R.J. Knight. 1995. Identification of cultivars and validation of genetic relationships in Mangifera indica $\mathrm{L}$. using RAPD markers. Theor. Appl. Genet. 90:269-274.

Sedra, M.H., P. Lashermes, P. Trouslot, M. Combes, and S. Hamon. 1998. Identification and genetic diversity analysis of date palm (Phoenix dactylifera L.) varieties from Morocco using RAPD markers. Euphytica 103:75-82.

Sparks, D. 1992. Pecan cultivars: The orchards foundation. Pecan Production Innovations., Watkinsville, Ga.

Taylor, W.A. 1906. Promising new fruits. Pecan, p. 504-508. In: G.W.
Hill (ed.). Yearbook of the U.S. Department of Agriculture Yearbook, 1905. U.S. Govt. Printing Office, Washington, D.C.

Thompson, T.E. and L.D. Romberg. 1985. Inheritance of heterodichogamy in pecan. J. Hered. 76:456-458.

Thompson, T.E. and F. Young. 1985. Pecan cultivars-Past and present. The Texas Pecan Growers Assoc., Inc., College Station, Texas.

Warburton, M.L. and F.A. Bliss. 1996. Genetic diversity in peach (Prunus persica L. Batch) revealed by randomly amplified polymorphic DNA (RAPD) markers and compared to inbreeding coefficients. J. Amer. Soc. Hort. Sci. 121:1012-1019.

Weising, K., H. Nybom, K. Wolff, and W. Meyer. 1995. DNA fingerprinting in plants and fungi. CRC Press, Ann Arbor, Mich.

Williams, J.G.K., A.R. Kubelik, J.L. Kenneth, J.A. Rafalski, and S.V. Tingy. 1990. DNA polymorphisms amplified by arbitrary primers are useful as genetic markers. Nucleic Acids Res. 18:6522-6531.

Wood, B.W. 1994. Edible tree nuts: Pecan and other hickories, p. 1-8. In: C.J. Arntzen and E.M. Ritter (eds.). Encyclopedia of agricultural science, vol. 2. Academic Press, New York.

Wood, B.W., L.J. Grauke, and J.A. Payne. 1998. Provenance variation in pecan. J. Amer. Soc. Hort. Sci. 123:1023-1028.

Wood, B.W., J.A. Payne, and L.J. Grauke. 1990. The rise of the U.S. pecan industry. HortScience 25:594-597.

Worley, R.E. 1974. 'Gloria Grande' pecan. Proc. Georgia Pecan Growers Assn. 9:75-80. 